\title{
Influence of Oenococcus oeni and Brettanomyces bruxellensis on Wine Microbial Taxonomic and Functional Potential Profiles
}

Zepeda-Mendoza, Marie Lisandra; Edwards, Nathalia Kruse; Madsen, Mikkel Gulmann; Abel-Kistrup, Martin; Puetz, Lara; Sicheritz-Pontén, Thomas; Swiegers, Jan H.

Published in:

American Journal of Enology and Viticulture

Link to article, DOI:

10.5344/ajev.2018.17092

Publication date:

2018

Document Version

Early version, also known as pre-print

Link back to DTU Orbit

Citation (APA):

Zepeda-Mendoza, M. L., Edwards, N. K., Madsen, M. G., Abel-Kistrup, M., Puetz, L., Sicheritz-Pontén, T., \& Swiegers, J. H. (2018). Influence of Oenococcus oeni and Brettanomyces bruxellensis on Wine Microbial Taxonomic and Functional Potential Profiles. American Journal of Enology and Viticulture, 69(4), 321-333. https://doi.org/10.5344/ajev.2018.17092

\section{General rights}

Copyright and moral rights for the publications made accessible in the public portal are retained by the authors and/or other copyright owners and it is a condition of accessing publications that users recognise and abide by the legal requirements associated with these rights.

- Users may download and print one copy of any publication from the public portal for the purpose of private study or research.

- You may not further distribute the material or use it for any profit-making activity or commercial gain

- You may freely distribute the URL identifying the publication in the public portal 


\section{Influence of Oenococcus oeni and Brettanomyces bruxellensis}

2 on Aged Wine Microbial Taxonomic and Functional Profiles

3 Marie Lisandra Zepeda-Mendoza ${ }^{1 *}$, Nathalia Kruse Edwards ${ }^{1}$, Mikkel Gulmann Madsen ${ }^{1}$, Martin

4 Abel-Kistrup ${ }^{1}$, Lara Puetz ${ }^{2}$, Thomas Sicheritz-Ponten ${ }^{3}$, Jan H. Swiegers ${ }^{1 *}$

$5 \quad{ }^{1}$ Chr. Hansen A/S, Bøge Allé 10, 2970 Hørsholm, Denmark.

$6 \quad{ }^{2}$ Centre for GeoGenetics, Natural History Museum of Denmark, University of Copenhagen. Øster

$7 \quad$ Voldgade 5-7, 1350 Copenhagen K, Denmark.

${ }^{3}$ Center for Biological Sequence Analysis, Department of Bio and Health Informatics, Technical University of Denmark, Anker Engelunds Vej 1 Bygning 101A, 2800 Kgs. Lyngby, Denmark.

*Corresponding authors: Jan H. Swiegers, e-mail: dkhsw@chr-hansen.com, Lisandra ZepedaMendoza, e-mail: dklize@chr-hansen.com

In the wine making process, the interactions between lactic acid bacteria (LAB), yeast and other wine microflora have an impact on the wine quality. In this study, we investigate the influence of the LAB Oenococcus oeni and the spoilage yeast Brettanomyces bruxellensis on the microbial community of a Cabernet Sauvignon wine. We generated metagenomic datasets from inoculations of three strains of $B$. bruxellensis, in combination with two $O$. oeni strains, one with and one without cinnamoyl esterase activity. This esterase activity releases hydroxycinnamic acids (HCAs) that can subsequently be processed by some $B$. bruxellensis strains able to generate off-flavor compounds. We evaluated the influence of the O. oeni and B. bruxellensis on the microbial taxonomic and functional potential profile, particularly regarding off-flavor formation due to HCAs. We found that the effect on the microbial profiles depends on $i$ ) the O. oeni and B. bruxellensis strains being combined and ii) the abundance they reach in the final wine, which depends on certain unidentified conditions. We confirmed that the potential of B. bruxellensis to produce off-flavor 
bioRxiv preprint first posted online Nov. 8, 2017; doi: http://dx.doi.org/10.1101/216390. The copyright holder for this preprint

(which was not peer-reviewed) is the author/funder, who has granted bioRxiv a license to display the preprint in perpetuity.

All rights reserved. No reuse allowed without permission.

compounds from HCAs depends on the strain. Interestingly, the samples without microbial inoculants also had this potential, suggesting that native grape microbiota could also influence the levels of HCA. We also found that the presence of $B$. bruxellensis does not interfere with the malolactic fermentation of the evaluated $O$. oeni strains, which leads to a less acidic taste. We show that metagenomic approaches can help uncover the complex wine microbial community traits, such as flavor, impacted by the simultaneous presence of $O$. oeni and $B$. bruxellensis.

Keywords: Microbiome, metagenomics, Brettanomyces bruxellensis, Oenococcus oeni, malolactic fermentation, alcoholic fermentation, hydroxycinnamic acids, off-flavor formation.

\section{Introduction}

\section{Wine-making and wine microbial interactions}

The study of the wine microbial ecosystem has mostly been focused on the two key fermentation players, Saccharomyces cerevisiae, which performs the alcoholic fermentation (AF), and Oenococcus oeni, which performs the malolactic fermentation (MLF), although other genus and species can also affect the wine characteristics. MLF is in fact a decarboxylation process where dicarboxylic L-malic acid (malate) is converted to monocarboxylic L-Lactic acid (lactate) and $\mathrm{CO}_{2}$, which can result in a rise in $\mathrm{pH}$. Thus, MLF softens the acid structure of the wine, as L-lactic acid is perceived as less acidic than L-malic acid. MLF usually starts spontaneously about 1-3 weeks after completion of AF and lasts 2-12 weeks. Furthermore, some carbohydrates are metabolized during MLF and there is release of phenolic acids and synthesis of esters, among other reactions, which are important for the wine flavour profile (Lonvaud-Funel n.d.). LAB naturally present in wine, or commercial strains isolated from wine, are normally used for MLF, with $O$. oeni being the preferable species due to its ethanol and acid tolerance and flavour profile (reviewed by Liu 2002 (Liu 2002)).

In the process of fermented food and beverage making, the starting ingredients can have associated indigenous microbial communities (Leff et al. 2013), which might vary depending on the source 
bioRxiv preprint first posted online Nov. 8, 2017; doi: http://dx.doi.org/10.1101/216390. The copyright holder for this preprint

(which was not peer-reviewed) is the author/funder, who has granted bioRxiv a license to display the preprint in perpetuity.

All rights reserved. No reuse allowed without permission.

and could have an impact on the final product characteristics. This has been investigated in wine, where the grape microbiota is influenced by cultivar, vintage, and climate (Bokulich et al. 2014).

Besides yeasts, such as Saccharomyces, and filamentous fungi, such as Aspergillus and Penicillium, a large bacterial diversity has been observed on grapes and must. The bacterial community is formed mainly by Proteobacteria, including acetic acid bacteria, and Firmicutes, including lactic acid bacteria (LAB) (reviewed by Barata et al. (2012) (Barata et al. 2012)). Some bacteria are plant or environmental microbes, while others have the physiological characteristics to allow them to grow on the harsh oenological conditions (Pina et al. 2004) (low nutrients, high acidity, ethanol concentrations of up to $15 \% \mathrm{v} / \mathrm{v}$ ), thus being able to form part of the wine microbiome (Barata et al. 2012). The microbial interactions, as well as their succession dynamics through the wine making process affect the hygienic and organoleptic properties of the final wine product (Sieuwerts et al. 2008). For example, Botrytis cinerea influences the microbial taxonomic profile through release of nutrients (Barata et al. 2008); one of those affected yeasts is the genus Metschnikowia, which can in turn prevent the growth of other fungi and bacteria by sequestering iron (Sipiczki 2006). Microbial interactions are also known to be highly strain specific. For example, a strain of S. cerevisiae has been shown to produce antimicrobial peptides under oenological conditions, which can inhibit growth of Brettanomyces bruxellensis (Branco et al. 2014). In the wine industry, B. bruxellensis is a spoilage yeast difficult to get rid of, mostly present in barrel aged wines (reviewed by Suarez et al. 2006 (Suarez et al. 2007)).

\section{Hydroxycinnamic acids}

A potential source of off-flavour compounds is hydroxycinnamic acids (HCAs). HCAs are organic acids, naturally present in grapes and wines, however, they are usually found as tartaric acid bound esters in grapes and wine. The content depends on the grape variety and growth conditions (Nagel \& Wulf 1979). This family of organic acids has been studied in wine and some food systems for its properties, such as colour stabilizing (Hernández et al. 2006), antioxidant (Bouzanquet et al. 2012), radical scavenging (Kikuzaki et al. 2002), and antimicrobial activity against some yeast and bacteria 
bioRxiv preprint first posted online Nov. 8, 2017; doi: http://dx.doi.org/10.1101/216390. The copyright holder for this preprint (which was not peer-reviewed) is the author/funder, who has granted bioRxiv a license to display the preprint in perpetuity. All rights reserved. No reuse allowed without permission.

(Ou \& Kwok 2004). However, the full effect of HCAs in food and in wine is not yet fully understood. Some LAB strains of Oenococcus and other Lactobacillus have been shown poses a cinnamoyl esterase activity, which releases HCAs from their bound form (Cabrita et al. 2008). It has been shown that the cinnamoyl esterase can also be present in different fungi (Rumbold et al. 2003). Furthermore, HCAs can also be released by chemical hydrolysis due to the acidity of the wine in a slow process that gradually continues through the winemaking and storage (Hixson et al. 2012). B. bruxellensis does not have the capability of producing free HCAs, however some strains possess a decarboxylase and a vinyl reductase activity, which can convert them into the off-flavour volatile phenols 4-ethylphenol and 4-ethylguaiacol, which confer the "Brettanomyces aroma" (Hixson et al. 2012). An increase in free HCAs could hereby potentially increase the risk of spoilage by a B. bruxellensis strain with both activities (reviewed by Kheir et al. 2013 (Kheir et al. 2013)). Importantly, Madsen et al. (2016) (Madsen et al. 2016) showed that the concentration of volatile phenols depends more on the strain of Brettanomyces than on the HCA esterase activity of O. oeni. Thus, the strain of B. bruxellensis is key in determining the volatile phenol concentration. Determination of the effect of a specifically selected starter or mixed-starter culture of yeast and bacteria on the wine profile cannot be effectively done without also characterizing the entire microbial community (Liu et al. 2017). Furthermore, although factors affecting yeast biodiversity have been widely documented, less characterization has been performed on the factors that influence the bacterial population. While several studies have characterized the microbiota on the grape surface and must, there is scarcity in the characterization of the microbial community in the final wine product. "Omics" methodologies in the food sciences, in particular in fermented goods, have been applied for the deeper and broader analysis of the microbial system relevant to both the fermentation process and the characteristics of the final product (De Filippis et al. 2017). In this study, we undertook a metagenomic approach to characterize the impact of the inoculations of two different strains of $O$. oeni (with and without the esterase activity) and three B. bruxellensis strains, alone and in combination, on the wine microbial community six months post-inoculation in a 
bioRxiv preprint first posted online Nov. 8, 2017; doi: http://dx.doi.org/10.1101/216390. The copyright holder for this preprint

(which was not peer-reviewed) is the author/funder, who has granted bioRxiv a license to display the preprint in perpetuity.

All rights reserved. No reuse allowed without permission.

104 Cabernet Sauvignon wine. We furthermore characterized the MLF activity in the inoculations by

105 measuring the abundance of malic acid.

106

\section{Materials and Methods}

108

109

110

\section{Wine inoculation}

Destemmed grape must from Cabernet Sauvignon before AF was imported from Bulgaria by Chr. Hansen A/S. S. cerevisiae strain NI6 was used for AF in $50 \mathrm{~L}$ tanks. The wine was pressed through filter cloths to remove grape seeds and skin. After mixing the wine by stirring, the wine was decanted into $5 \mathrm{~L}$ containers and stored at $5{ }^{\circ} \mathrm{C}$. The wine was measured on an Oenofoss and had an alcohol percent of $12.6 \%, 0.0 \mathrm{~g} / \mathrm{L}$ glucose and $0.0 \mathrm{~g} / \mathrm{L}$ fructose. The sulphite level was measured with a Megazyme kit and found to be $25 \mathrm{ppm}$. The $\mathrm{pH}$ was measured during MLF and remained at

\section{5 .}

Pure cultures of $B$. bruxellensis were stored on YGC agar to ensure viability of the yeasts

throughout the experiment. YGP broth was made with $5.0 \mathrm{~g}$ yeast extract, $10.0 \mathrm{~g}$ peptone and $11.0 \mathrm{~g}$ glucose monohydrate and milli-q water added until $1 \mathrm{~L}$ total volume in a conical flask. The mixture was dissolved using a magnetic stirrer. The $\mathrm{pH}$ was adjusted to 5.6 \pm 0.2 with $1 \mathrm{M}$ HCL and $1 \mathrm{M}$ $\mathrm{NaOH}$ and hereafter autoclaved at $121{ }^{\circ} \mathrm{C}$ for 15 minutes. The broth was kept in a refrigerator at 5 ${ }^{\circ} \mathrm{C}$ until use. CBS 73 had been frozen in glycol and was rejuvenated in YGP broth for 48 hours at $25^{\circ} \mathrm{C}$ before being inoculated into a new YGP broth, grown for 72 hours at $25^{\circ} \mathrm{C}$ and then plated on YGC agar. The two other strains were directly inoculated in YGP broth and then plated on YGC agar. All strains were incubated at $25^{\circ} \mathrm{C}$. A sample from each flask was counted after 72 hours on a hemocytometer (see 3.2) where the strains reached a level of approx. $10^{6}-10^{7} \mathrm{CFU} / \mathrm{mL}$. CBS 73 (Brett_A), CBS 2336 (Brett_B) and CBS 2499 (Brett_C) and were continually grown for 72 hours at $25^{\circ} \mathrm{C}$.

Two different strains of $O$. oeni were provided by Chr. Hansen $\mathrm{A} / \mathrm{S}$ and kept frozen at $-18{ }^{\circ} \mathrm{C}$. One of the $O$. oeni strains is cinnamoyl esterase negative (from here on referred to as OEN), while the 
bioRxiv preprint first posted online Nov. 8, 2017; doi: http://dx.doi.org/10.1101/216390. The copyright holder for this preprint

(which was not peer-reviewed) is the author/funder, who has granted bioRxiv a license to display the preprint in perpetuity.

All rights reserved. No reuse allowed without permission.

130 other is cinnamoyl esterase positive (from here on referred to as OEP), which can hereby potentially

131 liberate HCAs. $1.2 \mathrm{~g}$ frozen culture made for direct inoculation was dissolved in $200 \mathrm{~mL}$ sterilized

132 peptone water and $5 \mathrm{~mL}$ was added to $1 \mathrm{~L}$ of wine corresponding to an inoculation level of approx.

$133106 \mathrm{CFU} / \mathrm{mL}$. The cell concentrations in the YGP broth right before inoculation were determined

134 using a hemocytometer where cells were counted in the microscope.

135 Wine was collected from Chr. Hansen A/S in the morning of day 0 of MLF. Wine was poured into

13620 autoclaved $1 \mathrm{~L}$ blue-cap bottles and 4 autoclaved $5 \mathrm{~L}$ blue-cap bottles. Control wines were put

137 aside in a tempered room $\left(20^{\circ} \mathrm{C}\right)$. To minimize cross-contamination, the wines for MLF were then

138 inoculated with OEP and OEN and two wines of each (MLF control) were put aside in a tempered

139 room. The rest of the OEP wines were then inoculated with either Brett_A, Brett_B or Brett_C, one

140 at a time. Afterwards, the wines with OEN were inoculated also with the respective $B$. bruxellensis

141 strains. Control wines containing only B. bruxellensis were finally inoculated one strain at a time. $B$.

142 bruxellensis was inoculated at a concentration of approx. $5 \times 10^{2}$ by pipetting.

143 Measurement of MLF

144 An enzyme test-kit was used to measure the malic acid content. Samples were taken on days 0, 4, 7,

14510,14 and 114 from every bottle and frozen for later analysis using a malic acid enzyme test-kit (R-

146 Biopharm, Germany) and absorbance measurements on a spectrophotometer. A cuvette with 1.00

$147 \mathrm{~cm}$ light path was used at wavelength $340 \mathrm{~nm}$ at $20-25^{\circ} \mathrm{C}$. The cuvettes were prepared according to

148 the kit instructions. We calculated the malic acid concentration using the absorbance values.

\section{DNA extraction and sequencing}

150 The wines were sampled on day 114 after inoculation. The bottles of wine were gently swirled

151 before sampling to ensure proper mixing of the wine. Sterile B. Braun omnifix syringes without

152 needles were used to take samples from the bottles with a minimum of oxygen intake, although it

153 could not be entirely avoided. The samples were frozen at $-60{ }^{\circ} \mathrm{C}$ until analysis.

154 For DNA isolation, cells were pelleted from $50 \mathrm{~mL}$ of wine centrifuged at $4500 \mathrm{~g}$ for 10 minutes

155 and subsequently washed three times with $10 \mathrm{~mL}$ of $4^{\circ} \mathrm{C}$ phosphate buffered saline (PBS). The 
bioRxiv preprint first posted online Nov. 8, 2017; doi: http://dx.doi.org/10.1101/216390. The copyright holder for this preprint

(which was not peer-reviewed) is the author/funder, who has granted bioRxiv a license to display the preprint in perpetuity.

All rights reserved. No reuse allowed without permission.

pellet was mixed with G2-DNA enhancer (Ampliqon, Odense, Denmark) in $2 \mathrm{ml}$ tubes and incubated at RT for $5 \mathrm{~min}$. Subsequently, $1 \mathrm{~mL}$ of lysis buffer $(20 \mathrm{mM}$ Tris-HCl- $\mathrm{pH}$ 8.0, $2 \mathrm{mM}$ EDTA and $40 \mathrm{mg} / \mathrm{ml}$ lysozyme) was added to the tube and incubated at $37^{\circ} \mathrm{C}$ for one hour. An additional $1 \mathrm{~mL}$ of CTAB/PVP lysis buffer was added to the lysate and incubated at $65^{\circ} \mathrm{C}$ for one hour. DNA was purified from $1 \mathrm{~mL}$ of lysate with an equal volume of phenol-chloroform-isoamyl alcohol mixture 49.5: 49.5: 1 and the upper aqueous layer was further purified with a MinElute PCR Purification kit and the QIAvac 24 plus (Qiagen, Hilden, Germany), according to the manufacturer's instructions, and finally eluted in 100 ul DNase-free $\mathrm{H}_{2} \mathrm{O}$.

Prior to library building, genomic DNA was fragmented to an average length of $\sim 400$ bp using the Bioruptor $^{\circledR}$ XL (Diagenode, Inc.), with the profile of 20 cycles of $15 \mathrm{~s}$ of sonication and $90 \mathrm{~s}$ of rest. Sheared DNA was converted to Illumina compatible libraries using NEBNext library kit E6070L (New England Biolabs) and blunt-ended library adapters described by Meyer and Kircher (2010) (Meyer \& Kircher 2010). The libraries were amplified in $100-\mu \mathrm{L}$ reactions, with each reaction containing $20 \mu \mathrm{L}$ of template DNA, $10 \mathrm{U}$ AmpliTaq Gold polymerase (Applied Biosystems, Foster City, CA), 1× AmpliTaq Gold buffer, $2.5 \mathrm{mM} \mathrm{MgCl2,} 0.2 \mathrm{mM}$ of each dNTP, $0.2 \mathrm{uM}$ IS4 forward primer and $0.2 \mathrm{uM}$ reverse primer with sample specific 6 bp index. The PCR conditions were 12 minutes at $95^{\circ} \mathrm{C}$ to denature DNA and activate the polymerase, 14 cycles of $95^{\circ} \mathrm{C}$ for 20 seconds, $60^{\circ} \mathrm{C}$ annealing for 30 seconds, and $72^{\circ} \mathrm{C}$ extension for 40 seconds, and a final extension of $72^{\circ} \mathrm{C}$ extension for 5 minutes. Following amplification, libraries were purified with Agencourt AMPure XP (Beckman Coulter, Inc) bead purification, following manufacturer's protocol, and eluted in 50 uL of EB buffer (Qiagen, Hilden, Germany). The quality and quantity of the libraries were measured on the Bioanalyzer 2100 (Agilent technologies, Santa Clara, United States), and the libraries were pooled at equimolar concentration. Sequencing was performed on the Illumina HiSeq 2500 in PE100 mode following the manufacturer's instructions.

\section{Metagenomic taxonomic profiling}

The reads were first cleaned with cutadapt (Martin 2011) to remove adapter sequences and low 
bioRxiv preprint first posted online Nov. 8, 2017; doi: http://dx.doi.org/10.1101/216390. The copyright holder for this preprint (which was not peer-reviewed) is the author/funder, who has granted bioRxiv a license to display the preprint in perpetuity. All rights reserved. No reuse allowed without permission.

182 quality bases (min quality $=33,3$ '-end minimum quality $=30$, minimum length $=30$ ). In order to

183 evaluate the inoculation efficiency of the $O$. oeni and the $B$. bruxellensis strains, we mapped with

184 bwa v0.7.10 (Li \& Durbin 2009) the cleaned reads against the genomes of the O. oeni strains (in

185 house genomic sequences) and the published genome of B. bruxellensis (CBS 2499 v2.0) and

186 calculated the depth and breadth of coverage using samtools v1.3.1 and bedtools v.2.26. The

187 coverage statistics of $B$. bruxellensis were calculated excluding the scaffolds AHMD01000878.1,

188 AHMD01000885.1 and AHMD01000879.1, which contain rDNA tandem repeats, which we found

189 to artificially inflate the coverage due to mapping of reads likely deriving from other yeasts.

190 In order to characterize the microbial profiles of the inoculations, we used MGmapper (Petersen et

191 al. 2017) to first map the reads against the phi genome. The non-mapping reads were then used to

192 map against the next databases extracted from NCBI (2016/09/20) in "best mode": human, plant,

193 vertebrates, invertebrates, virus, fungi, protozoa, plasmid, and bacteria. The number of mapping

194 reads, coverage and depth were calculated, and the hits were annotated from the superkingdom to

195 the species taxonomic level. The identifications were filtered by taking into account the next

196 parameters: minimum abundance of $0.01 \%$, minimum ratio of unique mapping reads and total

197 mapping reads of 0.005 , maximum edit distance of 0.01 , and minimum of 10 mapping reads.

198 Metagenomic taxonomic comparison

199 In order to compare the microbial populations of the different inoculation samples we first built a

200 matrix with the number of reads mapping to the filtered identifications from all the samples and

201 normalized the counts by percentage of abundance. We used this matrix to $i$ ) identify the core

202 microbiomes of each type of inoculation, $i$ ) the diversity distance, $i i i$ ) to perform principal

203 component analysis (PCA), $i v$ ) differential abundance, and $v$ ) abundance correlation analyses using

204 R. The comparative analyses were performed excluding the out-layer samples with the highest and

205 lowest depth of sequencing (OEN_B_18 and OEN_23, respectively).

206 The taxonomic cores were obtained by identifying the microbes present in all the replicates of each 207 inoculation type. We calculated the microbial diversity distance between and within the inoculation 
bioRxiv preprint first posted online Nov. 8, 2017; doi: http://dx.doi.org/10.1101/216390. The copyright holder for this preprint

(which was not peer-reviewed) is the author/funder, who has granted bioRxiv a license to display the preprint in perpetuity.

All rights reserved. No reuse allowed without permission.

types using the R package vegan using the Bray, Jaccard, and Euclidean distances and clustered them with the ward.D and average methods. The differential abundance was performed using Fisher test with alternative hypotheses greater and less. We built the contingency tables using the mean of

211 the technical replicates of the inoculation types and performed the next comparisons: $i$ ) all the inoculation types versus the controls, $i i$ ) the combinations of OEP and the three B. bruxellensis

213 strains versus OEP, iii) the combinations of OEN and the three B. bruxellensis strains versus OEN, $214 i v$ ) OEP versus OEN, v) the combinations of each $B$. bruxellensis strain and the two $O$. oeni strains 215 versus the given $B$. bruxellensis strain. The p values $(P)$ were adjusted by the false discovery rate 216 (FDR) and the significant comparisons were those with FDR $\leq 0.05$.

217 The abundance correlations were performed with the R function cor.test using the Spearman 218 method. We removed from the normalized count matrix those identifications present in less than 10 219 samples. We defined two types of significant correlations $(P<0.05$ and rho $<-0.4$ or rho $>0.7)$ : a) 220 Unaffected correlations: the ones identified when comparing all the samples and when comparing without each of the inoculation types. b) Affected correlations: the ones that were identified only when removing one of the inoculation types. In order to identify the top 5\% abundant taxa in each sample, we normalized by depth of coverage. We also identified which top abundant species were present in all the technical replicates of each inoculation type.

\section{Metagenomic functional potential profiling}

The presence of HCA decarboxylase gene $(H c D)$ in the used B. bruxellensis strains was confirmed using lastz (Harris 2007) to identify the genomic region of the B. bruxellensis sequence used as reference containing the sequence of $H c D$ transcript id HQ693758.1 and using bedtools to extract the coverage of the mappings of the samples OEP_A_10, OEP_B_11, and OEP_C_13 (the ones with the highest coverage of each B. bruxellensis strain).

The cleaned reads were de novo assembled using IDBA-UD v1.1.1 (Peng et al. 2012) using the precorrection parameter in order to account for the uneven sequencing depths. Genes were then 
bioRxiv preprint first posted online Nov. 8, 2017; doi: http://dx.doi.org/10.1101/216390. The copyright holder for this preprint (which was not peer-reviewed) is the author/funder, who has granted bioRxiv a license to display the preprint in perpetuity. All rights reserved. No reuse allowed without permission.

predicted on the assemblies with prodigal v2.6.2 (Hyatt et al. 2010) using the meta mode.

Afterwards, the predicted genes of each sample were clustered using vsearch v2.1.2 (Edgar 2010) with an identity threshold of $95 \%$ and a minimum sequence length of 20 . The centroid sequence of each cluster was kept as the representative sequence to form a non-redundant (nr) gene set.

Afterwards, the nr gene sets were pooled and clustered using usearch with the same parameters to generate the final $\mathrm{nr}$ gene set catalogue used for the functional potential comparative analyses.

\section{Comparative analyses}

The reads of each sample were mapped against the nr gene set catalogue using bwa mem (Li \& Durbin 2009) to then obtain the coverage of each gene using samtools and bedtools. The coverage was used to build an abundance matrix. We then performed principal component analysis (PCA) on the normalized matrix using the function prcomp from $\mathrm{R}$ v3.2.0 with scaling. Given that sample OEN_23 was identified as an extreme outlayer and that the $O$. oeni inoculation did not succeed in this replicate, it was removed from the subsequent comparative functional potential analyses. As another method to evaluate the variation between and within the inoculation types, we calculated the Bray, Jaccard and Euclidean distances with the R package vegan using the abundance matrix and the values were clustered using the average and the ward.D methods.

Next, we assigned a KEGG orthology (KO) to the predicted nr genes using blastx with e-value 0.000001 against the KEGG database. The blast hits were filtered by a minimum bit score of 50 and minimum of $30 \%$ identity. A new abundance matrix was built for the genes with a KO identification. Subsequently, we identified KOs in differential abundance, i.e. statistically significant less or more abundant in a given inoculation type when compared to another inoculation type. To this end, we performed in R a Fisher test with the alternative hypothesis of greater and less and corrected $P$ using FDR. A contingency table for the Fisher tests using the mean of the replicates was made for comparing each of the inoculation types against the control, the OEP_A/B/C against OEP, OEN_A/B/C against OEN, OEN against OEP, and each of the $O$. oeni_A/B/C against the corresponding B. bruxellensis strain. We kept as statistically significant those with a FDR $\leq 5 \%$. 
bioRxiv preprint first posted online Nov. 8, 2017; doi: http://dx.doi.org/10.1101/216390. The copyright holder for this preprint (which was not peer-reviewed) is the author/funder, who has granted bioRxiv a license to display the preprint in perpetuity. All rights reserved. No reuse allowed without permission.

The differentially abundant KOs were then grouped by the pathways they are part of as annotated in KEGG and a two-sided Fisher test was performed as previously described for the KOs using as counts the number of differentially abundant KOs belonging to that pathway. We kept as significant those with $P \leq 0.05$. Then, we identified those differentially abundant pathways present in a minimum of 4 samples, those present only in the comparisons against the control, the OEP_A/B/C combinations against OEP, the OEN_A/B/C combinations against OEN, OEP against OEN, and the two $O$. oeni strains combined with each of the $B$. bruxellensis strains against the respective $B$. bruxellensis strain.

Furthermore, we identified the functional cores of the different inoculation types, defined as those $\mathrm{nr}$ genes present only in anyone of the replicates of each of the inoculation types. We also identified the most abundant genes in each of the samples as those within the top 5\% genes with highest counts and those present in the two replicates as top abundant were identified.

\section{Results}

\section{Taxonomic profiling}

A total of 534,135,264 sequencing reads were produced from all the samples ( $\min =1,899,372$, $\max =162,426,646$, average $=23,223,272.35)$, from where we obtained 523,937,023 cleaned reads $(\min =1,831,535, \max =159,467,366$, average $=22,779,870.57)($ Table 1, Supplemental File 1). Although two replicates were produced for each inoculation type and control, it was not possible to extract DNA from one of the replicates of the inoculation with OEP and Brett_C. Regarding the inoculation with only OEN, one of the replicates (OEN_23) has the lowest number of reads $(1,899,372)$. Thus, it was removed from the taxonomic and functional comparisons, as it would not capture the low abundant microbes identified by the other samples and it represented an extreme out layer in the evaluation of the functional potential profile with a PCA of all the samples due to its low sequencing depth (Supplemental Figure 1).

The sample OEN_B_18 has the highest number of reads $(162,426,646)$, thus it was removed from 
bioRxiv preprint first posted online Nov. 8, 2017; doi: http://dx.doi.org/10.1101/216390. The copyright holder for this preprint

(which was not peer-reviewed) is the author/funder, who has granted bioRxiv a license to display the preprint in perpetuity.

All rights reserved. No reuse allowed without permission.

the taxonomic comparisons, as it would bias for the identification of the very low abundant species

that the other samples would not capture. However, it was not removed from the functional

comparisons. Thus, for the taxonomic comparisons, the total number of species level identifications

pooling all the samples for the bacterial database was 918 (899 when removing the two out layer

samples), 117 plasmids (109 without out layer samples), 18 archaea, 11 viruses, 332 fungi (328

291 without out layer samples), and 96 protozoa.

\section{Inoculants abundance and functional evaluation}

We evaluated the abundance of $O$. oeni and B. bruxellensis in the wines 6 months after inoculation

(Table 1). The genome of $O$. oeni is covered at medium and high coverage in the two Brett_B

inoculations (70.65x and 420x). Also, one of the replicates of Brett_C has the genome of $O$. oeni at high coverage (399.8x), while the other is present in low abundance (14.3x). From the OEP_A replicates, one has the genome of $O$. oeni covered at medium coverage $(43.85 \mathrm{x})$ with the $B$.

bruxellensis strain at abundance similar to the other samples, while the other (sample OEP_A_10)

has $O$. oeni in high abundance (769.5x) and is also the sample with the second most abundant $B$.

alone. And OEP_C_13, which does not have a replicate, has the highest B. bruxellensis coverage

OEP_C_13.

To test whether the identified $O$. oeni bacteria in the wines not inoculated with it derive from the native grape flora, we evaluated the amount of MLF in the samples. We identified malic acid in the samples inoculated with OEN and OEP at day 114, but no malic acid in those not inoculated with

307 our O. oeni strains (Figure 1).

\section{Bacterial identifications}

309 In the PCA of the identified bacterial species (Figure 2A), most samples cluster tightly together

310 with the controls, with the most variable samples being from the Brett_C inoculation and the

311 Brett_A combined with both $O$. oeni strains. Brett_C_8 has the least number of bacterial 
bioRxiv preprint first posted online Nov. 8, 2017; doi: http://dx.doi.org/10.1101/216390. The copyright holder for this preprint

(which was not peer-reviewed) is the author/funder, who has granted bioRxiv a license to display the preprint in perpetuity.

All rights reserved. No reuse allowed without permission.

312 identifications (15), however it had much less depth of sequencing than its pair $(<25 \%)$, but similar

313 sequencing to other samples with more identifications and similar number of identifications to other

314 sample with double sequencing depth (Brett_A_3). Similarly, other inoculation types have a total

315 number of identifications uncorrelated to their depth of sequencing. For example, OEP_A_10 has

316 the highest number of identifications, and the pair has $~ 1 / 6$ of its sequencing depth (the sample with

317 second highest sequencing). However, it has similar number than OEN_A_15, which has less

318 sequencing than it. Also, the other samples with top highest sequencing have similar number of

319 identifications to the control samples (which have mean depth of sequencing).

Bacterial differential abundance

321 Regarding the differentially abundant identifications, OEN is the inoculation type with the lowest

322 number of bacteria present in higher abundance compared to the controls (33, while the mean is

323144.6 and median 144), Brett_A was the second, with 38 taxa, and OEP is the third with 54. In

324 regards to the number of species in less abundance compared to the controls, the inoculations with

325 only Brett_A have around the average $(118$, average= 120.1), while OEN has 141 and OEP_C has

326 the maximum (148) (Figure 2B). Interestingly, while Brett_A alone is the one changing the least the

327 bacterial community, it is also the one that changes it the most when inoculated together with $O$.

328 oeni (both OEP and OEN). Comparing the patterns of the number of higher and less abundant

329 species of all the inoculation types compared to the control, we observed that all the inoculation

330 types have similar amount of less abundant bacteria, with the largest difference being only in the

331 number of higher abundant bacteria in OEN_A and OEP_A. OEP_A had the highest number of

332 species present in higher abundance compared to the control (412, while the mean is 144.6 and the

333 median is 144), and OEN_A had the second highest number of species present in higher abundance

334 compared to the control (300). OEN was the one with the lowest number of bacteria present in

335 higher abundance compared to the control (33). Also, compared to Brett_A, both OEN_A and

336 OEP_A have low numbers of differentially less abundant bacteria (24 and 36, respectively). When

337 compared to OEP, OEN has 37 species in differentially higher abundance, and 142 in less 
bioRxiv preprint first posted online Nov. 8, 2017; doi: http://dx.doi.org/10.1101/216390. The copyright holder for this preprint (which was not peer-reviewed) is the author/funder, who has granted bioRxiv a license to display the preprint in perpetuity. All rights reserved. No reuse allowed without permission.

abundance.

339 In evaluating the taxonomic core of the inoculations, we found that the core of the OEN_A

340 inoculation type is the largest (Figure 3A). We also found that the number of species in the OEP_A 341 inoculation type core is not the highest (Figure 3A) while the distance of OEP_A to the control is 342 the largest (Figure 2CD).

\section{Abundance correlations and taxonomic distances}

344 The number of positive and negative taxonomic abundance correlations not affected by the 345 inoculation type (i.e. likely those that are due to the basic wine microbial community interactions) are almost the same (371 and 384, respectively) (Figure 3B). The inoculation type with the highest number of correlations disrupted by it is the addition of a B. bruxellensis strain (791 affected correlations), and the number of correlations affected by the OEP - B. bruxellensis combinations is the second highest $(617$, mean $=530$, median $=590.5)$. Furthermore, the number of correlations affected by the inoculation of $O$. oeni (187), while the number of affected correlation identified by the removal of the control samples (241). Furthermore, we did not identify any correlation affected by taking into account only one specific combination of $O$. oeni and B. bruxellensis, but there were affected correlations identified by taking into account the three possible combinations together for each O. oeni strain.

355 As expected, the distance between the controls is the lowest than that of the other samples compared to the controls (Figure 2CD). Interestingly, the distances of the samples inoculated only with $B$. bruxellensis are similar to those of OEN_A/B/C. The distance values also show that the inoculation type with the highest difference to the controls is the OEP_A/B/C, with one of the

359 OEP_A replicates being an out layer.

Plasmid and fungal identifications

361 Similar to the bacterial community, OEP is the closest to the control in the plasmid profiling 362 (Supplemental Figure 2A). Also, similar to the bacterial profiling, inoculation of Brett_A to OEN and OEP causes most plasmids to be in differential higher abundance than inoculation of the $O$. oeni 
bioRxiv preprint first posted online Nov. 8, 2017; doi: http://dx.doi.org/10.1101/216390. The copyright holder for this preprint (which was not peer-reviewed) is the author/funder, who has granted bioRxiv a license to display the preprint in perpetuity. All rights reserved. No reuse allowed without permission.

with Brett_B or Brett_C. Interestingly, only OEP_A_10 is an out layer very distant from the pair, with about double number of identifications than the pair, although it has similar number of identified plasmids to other samples. Brett_A_3 has the fewest plasmids and OEN_A_15 has the most. However, that is not the one with highest depth, and the ones with highest depth have similar number of plasmids as the others with mean depth of sequencing. Furthermore, both Brett_A_3 and OEN_A_15 cluster together within the main cluster.

Analysis of the fungal profile clusters tightly together in most of the samples (Supplemental Figure 2B). The only three samples placed outside the main cluster with the controls are one of the replicates of the combinations of OEP with each B. bruxellensis strain. To evaluate whether there is an increased potential to release HCAs due to fungal activity other than that of B. bruxellensis, we identified in our $\mathrm{nr}$ gene set catalogue sequences of the cinammoyl esterase gene from fungal origin. We could only find two genes, one originally annotated as from the yeast Pichia stipites. However, it was not annotated as esterase, but as triacylglycerol lipase with only $31.8 \%$ identity. The other gene was originally annotated as from the yeast Pichia pastoris; however, it was annotated with only $30.5 \%$ identity to an uncharacterized protein.

\section{Profiling of functional potential}

A total of 430,713 genes were predicted, with a mean of 18,726.65 per sample (Supplemental Figure 3), and a final nr gene set with all the genes from all the samples pooled was constructed containing a total of 70,991 $\mathrm{nr}$ genes. After filtering the low abundant ones and removing those present only in the removed OEN_23 sample for the comparative analyses, 50,604 were kept for functional annotation. A total of 41,350 of those genes were assigned a $\mathrm{KO}$ annotation, and we retained 40,525 $\mathrm{nr}$ genes after filtering out possible misannotations, accounting for 5,614 different KOs. The number of reads of the samples does not have an effect on the number of predicted genes (Pearson cor $=0.3667$ ), thus we did not exclude samples from the functional comparative analyses based on their sequencing depth (e.g. the sample OEN_B_18, which has the highest depth of sequencing). However, we excluded sample OEN_23 because it had the lowest depth of sequencing 
bioRxiv preprint first posted online Nov. 8, 2017; doi: http://dx.doi.org/10.1101/216390. The copyright holder for this preprint (which was not peer-reviewed) is the author/funder, who has granted bioRxiv a license to display the preprint in perpetuity. All rights reserved. No reuse allowed without permission.

and its functional profile was completely an out layer from the other samples, including its replicate pair (Supplemental Figure 1).

We identified a lot of functional potential variability, even within the controls (Figure 4A). OEN clusters close to OEP, which are closer to the control samples than any of the other samples. We identified variation in the functional potential between pairs of similar and different amount of sequencing. For example, the OEN_B replicates are functionally close in spite of the large difference is sequencing depth (they cluster in the same tight cluster not containing the controls). The two OEN_C replicates separate in two different tight clusters not containing the control samples and the two OEP_A replicates separate into two different clusters, one being a tight cluster containing OEP_A_9, and a loser one containing the control samples and OEP_A_10. This OEP_A pair is among the pairs most distant to each other. Furthermore, the sample with the least number of assembled nr genes was Brett_B_6 $(9,184)$ and OEP_A_10 had the highest $(41,618)$, although its depth of sequencing was not the lowest. The sample with the lowest depth of sequencing (OEN_23) and that with the highest (OEN_B_18) had assembled around the mean number of nr genes $(14,078$ and 19,651, respectively, mean=18,219.39).

\section{Differentially abundant functions}

We found that most of the differentially abundant KOs compared to the control are in lower abundance (average higher abundance $=1,221.8$, median higher abundance $=1,153$, average less abundance $=1,676.2$, median less abundance $=1,531)$. However, when assigning the KOs to pathways, more pathways are affected by KOs in higher abundance $($ average $=36.1$, median $=25$ ) than by those in lower abundance (average $=23$, median $=10$ ). Compared to the other inoculation types, Brett_A has the highest number of differentially abundant KOs in higher abundance $(2,748)$. Brett_A, OEP_A, OEN and OEN_C are the ones where there are more KOs in higher than in less abundance. However, OEN_A does not follow the same pattern of Brett_A and OEP_A (Figure 5A). We found that the inoculation only Brett_B and OEN_B had the highest numbers of differentially less abundant KOs compared to the control $(3,481$ and 3,582, respectively, average $=1,676.7$, 
bioRxiv preprint first posted online Nov. 8, 2017; doi: http://dx.doi.org/10.1101/216390. The copyright holder for this preprint (which was not peer-reviewed) is the author/funder, who has granted bioRxiv a license to display the preprint in perpetuity. All rights reserved. No reuse allowed without permission.

median= 1,531). OEP_B $(2,757)$ is in the fourth place, with OEP_C in the third $(3,200)$. O. oeni_B compared to Brett_B are the ones with the lowest number of KOs in differential less abundance compared to $O$. oeni_A/C, and OEN_B is the one with least KOs in higher abundance (335), although OEP_B is the one with the highest number of KOs present in higher abundance $(1,519)$. Brett_C has a similar number of higher and less abundant KOs (1,229 and 1,531, respectively) both around the means of higher and less of all the samples compared to the control $(1,221.8$ and 1,676.7, respectively). However, OEN_C is the second with the highest number of KOs present in higher abundance $(2,006)$, and OEP_C is the third with highest number of KOs present in less abundance $(3,200)$.

OEP has the least number of higher and less abundant KOs (24 and 39, respectively) compared to the control, while inoculations with only Brett_B and OEN_B had the highest numbers of differentially less abundant KOs compared to the control $(3,481$ and 3,582, respectively, average $=$ 1,676.7, median=1,531). Compared to OEP, OEN has more KOs present in higher abundance (956) than present in lower abundance (29). However, when looking at the pathways those KOs belong to (Figure 5B), only 10 pathways in higher and 10 in less abundance are identified, while the average is 36.14 as present in higher abundance, and 23 in lower abundance. Both replicates of inoculating only with OEP and OEN have the lowest total of differentially abundant KOs (63 and 1,477, respectively), while the inoculations with only $B$. bruxellensis have larger numbers of differentially abundant KOs. When analysing the pathways differentially abundant in only a given inoculation type derived from differentially abundant KOs, the comparisons of both OEP_C and OEN_C have the highest number of differentially less abundant pathways (52) (Figure 5C), with most of those differentially abundant KOs coming from OEP_C (2,068, while OEN_C has 593).

\section{Core and top abundant genes}

Out of the 40,525 annotated filtered nr genes, only 867 are present in all the compared samples. From all the B. bruxellensis and $O$. oen - B. bruxellensis combinations, Brett_A has the highest number of genes in its core (i.e. present in the two replicates of the inoculation type), with only 15 . 
bioRxiv preprint first posted online Nov. 8, 2017; doi: http://dx.doi.org/10.1101/216390. The copyright holder for this preprint

(which was not peer-reviewed) is the author/funder, who has granted bioRxiv a license to display the preprint in perpetuity.

All rights reserved. No reuse allowed without permission.

Inoculations of Brett_A alone have only 1 core gene (annotated as coming from Candida glabrata), while the other two inoculations of Brett_B and Brett_C have zero genes in the core. The O. oeni_B inoculations do not have genes in the core either, while $O$. oeni_C has only 9. OEN has only 16 core genes, much less core genes than OEP (329), but still in the third place compared to the other inoculation types. It is interesting that although OEP is the closest to the control, it is the second with the highest number of genes in its core $(329$, median $=2$, mean=67.15). As expected, the control samples are the ones with most genes in its core (515).

A total of 1,582 different $n r$ genes were found among the top abundant genes $(P<0.05)$ of all the inoculation types. The percentage of top abundant genes present in both replicates of each type of inoculation is in average $53.49 \%$ (median of $49.64 \%$ ), highlighting the variability in the wine microbial community. OEN_A has the lowest number of replicable genes present in top abundance in both replicates (Figure 5D) (only 5 genes), while both replicates have around the mean number of top abundant genes (580 and 646, mean=627.67). Notably, OEN_B has the highest percentage of replicable top abundant genes from the replicates $(80.2 \%, 355$, each replicate has 438 and 447 , which are below the mean and median).

\section{HCA derivatives}

To evaluate whether an increase in the release of HCA has the potential to produce more off-flavour compounds, we looked for genes in our nr gene set catalogue involved in the processing of HCAs. We identified a gene from Erwinia gerundensis (a cosmopolitan epiphyte) with $35.294 \%$ identity annotated with the KO K13727 (phenolic acid decarboxylase), which has decarboxylation activity on HCAs ferulic, p-coumaric and caffeic acids. This same gene had a second putative annotation with $73.864 \%$ identity to an unannotated protein from Nectria haematococca (Fusarium solani subsp. pisi), which is a fungal plant pathogen. This gene was also found to be significantly more abundant in Brett_A compared to Brett_B $\left(\mathrm{FDR}=4.16 \mathrm{e}^{-10}\right), \mathrm{OEP} \_\mathrm{A}(\mathrm{FDR}=0.0138), \mathrm{OEN}$-A (FDR= $\left.6.13 \mathrm{e}^{-5}\right)$, and control $\left(\right.$ FDR $\left.=2.91 \mathrm{e}^{-8}\right)$. It was also more abundant in Brett_C than in OEP_C $(F D R=$ 0.00027) and the control $\left(\mathrm{FDR}=4.54 \mathrm{e}^{-7}\right)$, in OEN_C than in OEN $\left(\right.$ FDR $\left.=1.27 \mathrm{e}^{-11}\right)$ and in control 
bioRxiv preprint first posted online Nov. 8, 2017; doi: http://dx.doi.org/10.1101/216390. The copyright holder for this preprint

(which was not peer-reviewed) is the author/funder, who has granted bioRxiv a license to display the preprint in perpetuity.

All rights reserved. No reuse allowed without permission.

$468\left(\mathrm{FDR}=3.22 \mathrm{e}^{-11}\right)$, and in OEP_A than in OEP $(\mathrm{FDR}=0.0014)$ and control $(\mathrm{FDR}=0.0012)$. We also

469 identified another KO related to the carboxylation of HCAs among our assembled genes; K20039

470 (ferulic acid decarboxylase 1-like) from S. cerevisiae, which was in significant higher abundance in

471 OEP_A compared to Brett_A (FDR= 0.00014) and in OEP_B compared to Brett_B (FDR=0.02).

472 Also, some genes with this KO were identified as less abundant in OEP_B and OEP_C compared to

473 OEP $\left(\mathrm{FDR}=0.01\right.$ and $\mathrm{FDR}=3.82 \mathrm{e}^{-9}$, respectively $)$, and the control $\left(\mathrm{FDR}=0.013, \mathrm{FDR}=2.10 \mathrm{e}^{-9}\right.$,

474 respectively). Other genes annotated as ferulic acid decarboxylase 1-like were in significant less

475 abundance in OEN_A/B/C compared to OEN $\left(F D R=2.1 \mathrm{e}^{-10}, F D R=5.25 \mathrm{e}^{-8}, F D R=4.17 \mathrm{e}^{-8}\right.$,

476 respectively) and the control $\left(\mathrm{FDR}=1.19 \mathrm{e}^{-7}, \mathrm{FDR}=1.88 \mathrm{e}^{-5}, \mathrm{FDR}=8.92 \mathrm{e}^{-6}\right)$, and less abundant in the

477 Brett_A/B/C compared to the control $\left(\mathrm{FDR}=1.99 \mathrm{e}^{-6}, \mathrm{FDR}=3.55 \mathrm{e}^{-7}, \mathrm{FDR}=1.23 \mathrm{e}^{-8}\right.$, respectively).

\section{Discussion}

\section{Microbial taxonomic and functional potential profiling}

\section{General wine-related identifications}

Among the taxonomic identifications, we found expected bacteria derived from soil and plants,

such as Xanthomonas alfalfa, Dyella japonica and Micrococcus luteus (found on the surface of

table grapes). We also identified wine spoilage bacteria, such as Aeromonas hydrophila in various

samples. In regards to the number of bacterial identifications, it is interesting to note that we found

Bodo saltans (Pleuromonas jaculans) in top abundance in OEP_B_12 (at 308.2x coverage),

OEN_24 (126.57x), both OEN_C replicates, OEN_A_16, and Brett_A_3 (mean coverage of 21.57x).

It is a free-living nonparasitic protozoan which feeds upon bacteria which can be found in

489 freshwater and marine environments. These samples that have it in top abundance also have less

490 bacterial identifications compared to the rest or compared to their respective pair. However, the

491 causal relationship cannot be identified, although it deserves further study.

492 Among the top abundant bacteria identified in OEP combined with a B. bruxellensis strain, we

493 found several LAB that are examples of bacteria being promoted as an effect of the use of a specific 
bioRxiv preprint first posted online Nov. 8, 2017; doi: http://dx.doi.org/10.1101/216390. The copyright holder for this preprint

(which was not peer-reviewed) is the author/funder, who has granted bioRxiv a license to display the preprint in perpetuity.

All rights reserved. No reuse allowed without permission.

O. oeni strain with B. bruxellensis. For instance, we identified Lactobacillus collinoides, a LAB found in cider, in one of the replicates of each OEP_A/B/C combination in higher abundance compared to the respective $B$. bruxellensis strain and to OEP and the controls. In similar differential abundance pattern, we found among the top abundant bacteria Lactobacillus crustorum, isolated from two traditional Belgian wheat sourdoughs, Lactobacillus herbarum, a species related to Lactobacillus plantarum, Lactobacillus oeni, LAB isolated from wine, and Lactobacillus paucivorans, isolated from a brewery environment. Among the top abundant bacteria identified in higher differential abundance in each OEP_A/B/C compared to the respective $B$. bruxellensis strain, to OEP and the controls, we identified Lactobacillus nagelii, isolated from a partially fermented wine, and Lactobacillus parafarraginis, a heterofermentative lactobacilli isolated from a compost of distilled shochu residue.

Among the fungi in differentially higher abundance in OEN_A when compared to Brett_A, OEN and the control, and in OEN_B/C when compared to OEN, we identified Talaromyces stipitatus. This fungus contains genes with high identity to those needed for the biosynthesis of the red pigment monascorubrin by the phylogenetic relative fungi Talaromyces marneffei. Interestingly, we also identified T. marneffei differentially abundant only in in OEP_C when compared to Brett_C, OEP and control. As expected, we also identified other grape-related fungi, such as the plant pathogens Verticillium dahlia and Verticillium longisporum, Mucor ambiguus, present in soil and plants, and the wine common yeast Saccharomyces cerevisiae and Lachancea kluyveri (found in the core of OEP_C).

In regards to AF, we identified in various samples the fungi Mucor indicus, previously isolated from the traditional fermented Indonesian food tempeh, and with the capability of producing ethanol is comparable with that of $S$. cerevisiae. Also, in one OEP_C sample we identified Candida sorboxylosa, an ethanol producing and tolerant yeast species from fruits for production of bioethanol that is common to the winery environment. 
bioRxiv preprint first posted online Nov. 8, 2017; doi: http://dx.doi.org/10.1101/216390. The copyright holder for this preprint (which was not peer-reviewed) is the author/funder, who has granted bioRxiv a license to display the preprint in perpetuity. All rights reserved. No reuse allowed without permission.

520 We identified no malic acid on day 114 in the samples not inoculated with our $O$. oeni culture

521 strains (Figure 1), suggesting that the found high coverage of $O$. oeni in the samples not inoculated 522 with them (one replicate of Brett_A and Brett_C, and the two Brett_B replicates) derives from $O$. oeni present in the native grape flora. From the three tested B. bruxellensis strains, Brett_B seems to be unable to grow in these wines, because when inoculated alone it was identified at only $0.4 \mathrm{x}$, and when inoculated with $O$. oeni, it was identified in very low abundance (Table 1, Supplemental File 1). The difference in the genome depths of coverage in the replicates of the $O$. oeni and $B$. bruxellensis strains inoculated together suggest that $B$. bruxellensis sometimes grows well and sometimes not, depending on certain unidentified conditions. Such inability to predict with precision the activity of a spoilage yeast and its effect on the entire microbial community highlights the importance in wine-making of inoculating with sufficient numbers of strong and viable yeast 531 and bacteria to ensure the presence of the desired microbial community (Gerbaux et al. 2009). 532 In the identification of bacterial species from plasmids, all the inoculation types seem to have an 533 effect on the community compared to the controls, while on the bacterial community there was an 534 effect only for certain inoculation types. This suggests that the plasmids presence is inherently 535 variable, although to a low extent. The fact that OEP_A_10 has similar number of identified 536 plasmids to other samples in spite of being an out layer very distant from the pair (with about 537 double number of identifications than the pair) suggests that the difference in the plasmid profile 538 resides on the bacterial community (the plasmids hosts). Also, the differences in the number of 539 plasmids identified in the samples compared to their depth of sequencing, suggests that the number 540 of identifications is not mainly due to depth of sequencing.

541 Interestingly, while the number of reads of the samples has a moderate influence on the number of 542 identified taxa (Pearson cor=0.6832), it does not have an effect on the number of identified genes 543 (Pearson cor= 0.3667). Furthermore, the number of identified taxa has a moderate correlation to the 544 number of identified genes (Pearson cor= 0.6854), and the number of nr genes directly correlates 545 with the number of genes in all the samples (Pearson cor= 0.997) (Supplemental Figure 3). This 
bioRxiv preprint first posted online Nov. 8, 2017; doi: http://dx.doi.org/10.1101/216390. The copyright holder for this preprint (which was not peer-reviewed) is the author/funder, who has granted bioRxiv a license to display the preprint in perpetuity. All rights reserved. No reuse allowed without permission.

suggests that the functional potential space of the wine microbiome is more defined than the taxonomic profile. However, we also identified functional potential variation between pairs of similar and different amount of sequencing, suggesting that the observed variability in the functional potential is not due to differences in depth of sequencing. Interestingly, the variability is such that even the controls do not cluster tightly together as in the taxonomic PCAs. But, similarly to the impact of $B$. bruxellensis in the taxonomic identifications, most of the impact when $O$. oeni is inoculated occurs when combining it with a B. bruxellensis, as OEN and OEP are the closest to the control samples. These results suggest that the main changes in the wine microbial community occur when B. bruxellensis is present.

In contrast to the taxonomic profiling, where most of the taxa of the different inoculation types compared to the control was in statistically significant higher abundance, at the functional level most of the differentially abundant KOs compared to the control are in less abundance. However, the assignation of the KOs to pathways showed that more different pathways are affected by KOs in higher abundance than by those in less abundance. This suggests that there is a need of a minimum set of present pathways required by the wine microbiome to tribe in that particular system; such minimum set can be perturbed by changes in the component KOs, however such changes do not disrupt the entire pathway. Elimination of the presence of a KO (i.e. differentially less abundant $\mathrm{KO})$ is more disruptive to a pathway than a $\mathrm{KO}$ being present in higher abundance.

The fact that only the control and OEP have a large number of genes as core, but that the OEP and the control samples are functionally the closest types of inoculation, suggests that the main effect on the functional profiles of the different inoculations is not in the integration of new functions, but in changes in their abundance.

\section{O. oeni - B. bruxellensis strain specific dependent effect}

We observed that in general, the samples inoculated with B. bruxellensis have less bacterial identifications (mean 71, average all samples 152.4, median all samples 129) than the ones inoculated with an O. oeni strain (Supplemental File 1). This suggestion is supported by the 
bioRxiv preprint first posted online Nov. 8, 2017; doi: http://dx.doi.org/10.1101/216390. The copyright holder for this preprint (which was not peer-reviewed) is the author/funder, who has granted bioRxiv a license to display the preprint in perpetuity. All rights reserved. No reuse allowed without permission.

correlation abundance results. If the effect of the addition of a B. bruxellensis strain is the elimination of several taxa, it would be expected that most of the affected correlation were those that used to be positive. Effectively, $79.6 \%$ of the affected correlations were positive.

The fact that both replicates of inoculating only with OEP and OEN cluster together with the controls and have the lowest total of differentially abundant KOs (63 and 1477, respectively), while the inoculations with only B. bruxellensis strains have larger numbers of differentially abundant KOs, suggests that most of the functional potential impact is given by the B. bruxellensis strain than by the $O$. oeni strain.

Also, the clustering patterns on the PCA of the taxonomic identifications suggest that the combination of $O$. oeni and $B$. bruxellensis has an impact on the bacterial composition depending on the strains being combined, both between and within inoculation types. It also suggests that in some instances the presence of more of low abundant bacteria and difference in abundance of the same bacteria accounts for the variation within the same inoculation type, rather than a radical change in the bacterial composition.

The observation that $O$. oeni and B. bruxellensis have an impact on the bacterial composition depending on the specific strains being combined, both between and within inoculation types, is supported by the abundance correlation analyses. Correlations were not affected when taking into account only one specific combination of $O$. oeni and B. bruxellensis, but when taking into account the three possible combinations together for each $O$. oeni strain. In other words, the effect of OEP_A is not the same as that of OEP_B and OEP_C, and also that of OEN_A is not the same as OEN_B and OEN_C. Also, when looking at the functional potential evaluation, we found that compared to the other inoculation types, Brett_A and OEP_A are among those with the highest number of differentially higher abundant KOs. However, OEN_A does not follow the same pattern of Brett_A and OEP_A. This further supports the suggestion that the functional impact of Brett_A depends on the O. oeni it interacts with (Figure 5A). Interestingly, in spite of the observation that OEN_B is the one with least KOs in greater abundance 
bioRxiv preprint first posted online Nov. 8, 2017; doi: http://dx.doi.org/10.1101/216390. The copyright holder for this preprint (which was not peer-reviewed) is the author/funder, who has granted bioRxiv a license to display the preprint in perpetuity. All rights reserved. No reuse allowed without permission.

while OEP_B is the one with the highest number of KOs present in higher abundance, the inoculations of only Brett_B, OEN_B, and OEP_B are among the samples with the highest numbers of differentially less abundant KOs compared to the control. This suggests that Brett_B reduces the

601 functional potential of the system, regardless of the $O$. oeni it is inoculated with. On the other hand, 602 Brett_C has a similar number of higher and less abundant KOs compared to the control. However, 603 OEN_C is the second with the highest number of KOs present in higher abundance and OEP_C is 604 the third with highest number of KOs present in less abundance. This suggests that the effect of 605 Brett_C on the functional potential depends on the $O$. oeni strain.

Notably, although OEN_A and OEN_C have the least number of replicable top abundant genes, the OEN_B samples have the highest percentage of replicable top abundant genes, suggesting that the OEN_B functional profile is more replicable and less variable than that of the other inoculation types, again highlighting the different impact in the microbial communities that $O$. oeni strains have depending on the B. bruxellensis strain present.

611 The observation that the inoculations of Brett_A together with both OEN and OEP have low 612 numbers of differentially less abundant bacteria suggests that the inoculation of Brett_A with $O$. 613 oeni seems to impact the community by allowing the growth of more bacterial taxa instead of by 614 repressing their growth. Although the large variability within the OEP_A inoculation type is likely 615 due to the ability of the Brett_A to grow poorly or successfully with OEP, this same effect is not observed in OEN_A, bec ause in OEN_A one replicate grew more than the other, but the core of the OEN_A inoculation type is the largest (Figure 3A). Among them, we found Lactobacillus paracollinoides, isolated from brewery environments, Lactobacillus pentosus, the most prevalent

619 lactic acid bacterium in Spanish-style green olive fermentations, and Staphylococcus equorum, 620 frequently isolated from fermented food products and contributing to the formation of aroma 621 compounds during ripening, especially in cheeses and sausages.

\section{O. oeni strain specific effect}


bioRxiv preprint first posted online Nov. 8, 2017; doi: http://dx.doi.org/10.1101/216390. The copyright holder for this preprint

(which was not peer-reviewed) is the author/funder, who has granted bioRxiv a license to display the preprint in perpetuity.

All rights reserved. No reuse allowed without permission.

OEP is the closest to the control and is among the inoculation types with least bacteria present in higher abundance. This suggests that the inoculation type that affects the least the wine microbial profile (after 6 months of inoculation) is that of a single $O$. oeni strain. This is supported by the microbial abundance correlation analyses, where the number of correlations affected by the inoculation of $O$. oeni is close to the number of affected correlation identified by the removal of the control samples. Furthermore, OEP has the least number of higher and less abundant KOs compared to the control, and its functional potential diversity clusters together with the controls (Figures 4B, $5 \mathrm{~A})$, suggesting that OEP causes the least change in the functional potential compared to the other inoculation types. Compared to OEP, OEN has more KOs present in higher abundance than present in less abundance, however, when looking at the pathways those KOs belong to (Figure 5B), only 10 pathways in higher and 10 in less abundance are identified. These observations suggest that the degree of functional impact of those $O$. oeni strains alone is similar.

We observed low numbers of replicable genes present in the 5\% top abundant genes in both replicates of OEN_A (Figure 5D), although they have around the mean number of top abundant genes. This is likely due to the difference in abundance of $O$. oeni; one of the replicates had $O$. oeni in high abundance, while the other had the $O$. oeni in very low abundance and the $B$. bruxellensis in moderate abundance.

\section{The effect of the abundance of $B$. bruxellensis}

Interestingly, in the viral profiling, in OEN_A we identified in higher abundance compared to the control two viruses against fungi, Phytophthora infestans RNA virus 1 and Saccharomyces cerevisiae killer virus M1 (also in higher abundance in OEN_B). It could be that these viruses contribute to a reduction of the fungal diversity in this OEN - B. bruxellensis combinations compared to those combined with OEP, where fungal diversity seems to be increased. However, this would need further experimental validation.

Notably, when checking the pathways differentially abundant in only a given inoculation type derived from differentially abundant KOs, the comparisons of O. oeni_C versus Brett_C have the 
bioRxiv preprint first posted online Nov. 8, 2017; doi: http://dx.doi.org/10.1101/216390. The copyright holder for this preprint

(which was not peer-reviewed) is the author/funder, who has granted bioRxiv a license to display the preprint in perpetuity.

All rights reserved. No reuse allowed without permission.

highest number of differentially less abundant pathways (Figure 5C), with most of those differentially abundant KOs coming from OEP_C. This suggests that OEP combined with a successfully growing Brett_C causes a large impact on the functional potential of the wine microbial community. Among the differentially abundant pathways present in less abundance in the comparisons of $O$. oeni_C versus Brett_C is the regulation of mitophagy in yeast, with all the KOs of the pathway in less abundance in OEP_C, possibly suggesting there is less potential of regulation of the fungal taxonomic profile in OEP_C. This is interesting, as the fungal profile in OEP_C is the second with the highest number of differentially more abundant fungal species when compared to the control (61, while the mean is 30.54 and median is 14).

The observation that OEP alone is closest to the control in the taxonomic profiling, and that it has a strong effect on the bacterial profile when B. bruxellensis is in high abundance is notable, given that HCAs have been shown to inhibit the growth of many microorganisms (Kheir et al. 2013).

Furthermore, there is evidence that the concentration of 4-ethylphenol and 4-ethylguaiacol is lower when malolactic bacteria are present before exposure to Brettanomyces, so that it has been

suggested to inoculate with commercially available strains as the time needed for spontaneous MLF is unpredictable giving prolonged risk for exposure of B. bruxellensis (Nielsen \& Richelieu 1999).

\section{Flavour potential}

\section{Taxonomic and functional potential identifications}

In regards to taxonomic identifications related to flavour formation in wine, we found only in the OEP_C sample the bacterium Lactobacillus diolivorans (176 mapping reads), which degrades 1,2propanediol, a compound that is nearly odourless but that possesses a faintly sweet taste. Also, only in this sample we found the fungi Clavispora lusitaniae (596 mapping reads), which has been found to produce a good balance between concentrations of ethyl acetate (sweet smell) and high alcohols. In regards to potential functions, the $\beta$-glucosidase activity is involved in the hydrolysis of several important compounds for the development of varietal wine flavour profiles, and microbial $\beta$ glucosidases have been used for the enhancement of wine aroma. Importantly, glucosydases not 
bioRxiv preprint first posted online Nov. 8, 2017; doi: http://dx.doi.org/10.1101/216390. The copyright holder for this preprint (which was not peer-reviewed) is the author/funder, who has granted bioRxiv a license to display the preprint in perpetuity. All rights reserved. No reuse allowed without permission.

encoded by $S$. cerevisiae have been shown to impact the flavour compounds profile in wine (Rosi et al. 1994). In our nr gene set we identified 53 genes annotated as KO K05349 (bglX; betaglucosidase) from many different bacteria and non-Saccharomyces yeast. One of them is in top abundance in various samples and is annotated as coming from O. oeni. However, sensorial evaluation is required to assess the impact in the wine flavour due to these identified genes.

$M L F$

To evaluate whether the presence of $B$. bruxellensis affects the occurrence of MLF, and thus its effect in reducing the acidity of the wine, we looked for genes annotated as malate dehydrogenase $(m d h)$ in our nr gene set. We identified $m d h$ in differential abundance in various comparisons and coming from various species, including $O$. oeni. As expected, the two genes annotated as $m d h$ and D-lactate dehydrogenase from $O$. oeni are in the top abundant in all the samples inoculated with $O$. oeni strains and $O$. oeni combined with a $B$. bruxellensis strain, and also in Brett_B/C. Thus, the presence of the analysed B. bruxellensis strains does not affect the MLF activity of the evaluated $O$. oeni strains.

\section{HCA production}

The cinnamoyl esterase activity can also be present in different fungi, suggesting that under certain unidentified conditions, the variability of fungi promoted by the combination of OEP with a well growing $B$. bruxellensis could possess this esterase activity and contribute to the increase in the production of HCAs. However, we could only find two yeast genes with inconclusive functional annotations. Thus, it cannot be concluded that there is a higher production of HCA due to the potential activity of other fungi, further experimental functional characterization should be performed on these identifications to validate whether they confer the cinammoyl esterase activity.

The observations from the abundances of the phenolic acid decarboxylase and ferulic acid decarboxylase 1-like genes also suggest that the presence of genes with putative decarboxylase activity on HCAs is not dependent on the presence of a specific O. oeni strain with or without the esterase activity, but on the B. bruxellensis strain, because it is also in the control samples and 
bioRxiv preprint first posted online Nov. 8, 2017; doi: http://dx.doi.org/10.1101/216390. The copyright holder for this preprint

(which was not peer-reviewed) is the author/funder, who has granted bioRxiv a license to display the preprint in perpetuity.

All rights reserved. No reuse allowed without permission.

because Brett_A has higher abundance of phenolic acid decarboxylase than OEP_A.

\section{Conclusions}

705 In this study, we characterized the impact on the microbial community of a Cabernet Sauvignon wine six months post-inoculation of two different strains of $O$. oeni (with and without the cinnamoyl esterase activity) and three $B$. bruxellensis strains, alone and in combination. We found that the impact in the taxonomic profile and functional potential of the microbiome due to the $O$. oeni - B. bruxellensis combinations depends on $i$ ) the specific $O$. oeni and B. bruxellensis strains

710 being combined, and $i$ ) the abundance reached by the inoculants, which depends on certain 711 unidentified conditions. Analysis of the functional potential of the system identified that changes in

712 the abundance of the genes is the general effect of the inoculations, not integration of new

713 functions. OEP maintains the stability of the most abundant functions in the system in spite of the 714 addition of the $B$. bruxellensis. The functional potential for the $\mathrm{HcD}$ activity is dependent on the $B$. 715 bruxellensis strain; however, the control samples also have this potential, not derived from the inoculated B. bruxellensis nor from the $O$. oeni strains. Furthermore, it was not possible to identify non-Brettanomyces fungal potential to produce HCAs as a result from a particular inoculation type. Finally, the HCAs post processing into off-flavor compounds is not dependent on the $O$. oeni but on the $B$. bruxellensis strain and other microbes, likely derived from the indigenous grape flora. This study proves the usefulness of metagenomic analysis in obtaining a deeper insight into the general microbial profile characteristics and the impact of specific inoculants, not only in the taxonomy, but also in the functional potential of the system. However, experimental validation will be necessary in future studies to obtain a detailed knowledge of the specific mechanisms of the interactions identified with metagenomic analyses. Also, sensorial analysis would be necessary to evaluate the impact on the flavor profile of the wines produced by the potential unveiled by the metagenomic results. 
bioRxiv preprint first posted online Nov. 8, 2017; doi: http://dx.doi.org/10.1101/216390. The copyright holder for this preprint

(which was not peer-reviewed) is the author/funder, who has granted bioRxiv a license to display the preprint in perpetuity.

All rights reserved. No reuse allowed without permission.

\section{Acknowledgements}

MLZM, MAK and LP thank the Danish National Advanced Technology Foundation

(Højteknologifonden) 080-2012-3-Food genomics and Innovation Fund Denmark case number 6150-00033A FoodTranscriptomics for funding the research. The authors declare no conflict of interests. We thank the Danish National High-Throughput DNA Sequencing Centre for the generation of the sequencing data. We gratefully acknowledge the Danish National Supercomputer for Life Sciences - Computerome (computerome.dtu.dk) for the computational resources to perform the sequence analyses. The sequencing data reported in this paper will be archived in a public database (ID added upon paper acceptance).

Short version of title: $O$. oeni - B. bruxellensis impact on wine microbiome

\section{Literature Cited}

Barata A et al. 2008. Ascomycetous yeast species recovered from grapes damaged by honeydew and sour rot. Journal of applied microbiology 104(4):1182-91.

Barata A, Malfeito-Ferreira M and Loureiro V. 2012. The microbial ecology of wine grape berries. International Journal of Food Microbiology 153(3):243-259.

Bokulich NA et al. 2014. Microbial biogeography of wine grapes is conditioned by cultivar, vintage, and climate. Proceedings of the National Academy of Sciences of the United States of America 111(1):E139-48.

Bouzanquet Q et al. 2012. A Novel Glutathione-Hydroxycinnamic Acid Product Generated in Oxidative Wine Conditions. Journal of Agricultural and Food Chemistry 60(49):12186-12195. Branco P et al. 2014. Identification of novel GAPDH-derived antimicrobial peptides secreted by Saccharomyces cerevisiae and involved in wine microbial interactions. Applied Microbiology and Biotechnology 98(2):843-853.

Cabrita MJ et al. 2008. Impact of malolactic fermentation on low molecular weight phenolic compounds. Talanta 74(5):1281-1286. 
bioRxiv preprint first posted online Nov. 8, 2017; doi: http://dx.doi.org/10.1101/216390. The copyright holder for this preprint

(which was not peer-reviewed) is the author/funder, who has granted bioRxiv a license to display the preprint in perpetuity.

All rights reserved. No reuse allowed without permission.

754 Edgar RC. 2010. Search and clustering orders of magnitude faster than BLAST. Bioinformatics

755 (Oxford, England) 26(19):2460-1.

756 De Filippis F, Parente E and Ercolini D. 2017. Metagenomics insights into food fermentations.

757 Microbial Biotechnology 10(1):91-102.

758 Gerbaux V et al. 2009. Influence of Inoculation with Malolactic Bacteria on Volatile Phenols in

759 Wines. American Journal of Enology and Viticulture 60(2):233-235.

760 Harris RS. 2007. Improved Pairwise Alignment of Genomic DNA. ProQuest.

761 Hernández T et al. 2006. Phenolic compounds in red wine subjected to industrial malolactic

762 fermentation and ageing on lees. Analytica Chimica Acta 563(1-2):116-125.

763 Hixson JL et al. 2012. Hydroxycinnamic Acid Ethyl Esters as Precursors to Ethylphenols in Wine.

764 Journal of Agricultural and Food Chemistry 60(9):2293-2298.

765 Hyatt D et al. 2010. Prodigal: prokaryotic gene recognition and translation initiation site

766 identification. BMC bioinformatics 11:119.

767 Kheir J et al. 2013. Impact of volatile phenols and their precursors on wine quality and control

768 measures of Brettanomyces/Dekkera yeasts. European Food Research and Technology 237(5):655769671.

770 Kikuzaki H et al. 2002. Antioxidant properties of ferulic acid and its related compounds. Journal of 771 agricultural and food chemistry 50(7):2161-8.

772 Leff JW et al. 2013. Bacterial Communities Associated with the Surfaces of Fresh Fruits and

773 Vegetables. PLoS ONE 8(3):e59310.

774 Li H and Durbin R. 2009. Fast and accurate short read alignment with Burrows-Wheeler transform.

775 Bioinformatics (Oxford, England) 25(14):1754-60.

776 Liu SQ. 2002. A review: malolactic fermentation in wine -- beyond deacidification. Journal of 777 applied microbiology 92(4):589-601.

778 Liu Y et al. 2017. Wine microbiome: A dynamic world of microbial interactions. Critical Reviews

779 in Food Science and Nutrition 57(4):856-873. 
bioRxiv preprint first posted online Nov. 8, 2017; doi: http://dx.doi.org/10.1101/216390. The copyright holder for this preprint

(which was not peer-reviewed) is the author/funder, who has granted bioRxiv a license to display the preprint in perpetuity.

All rights reserved. No reuse allowed without permission.

Lonvaud-Funel A. 1999. Lactic acid bacteria in the quality improvement and depreciation of wine. Antonie van Leeuwenhoek 76(1-4):317-31.

Madsen MG et al. 2016. Influence of Oenococcus oeni and Brettanomyces bruxellensis on Hydroxycinnamic Acids and Volatile Phenols of Aged Wine. American Journal of Enology and Viticulture doi: 10.5344/ajev.2016.16015.

Martin M. 2011. Cutadapt removes adapter sequences from high-throughput sequencing reads.

EMBnet.journal 17(10).

Meyer M and Kircher M. 2010. Illumina sequencing library preparation for highly multiplexed target capture and sequencing. Cold Spring Harbor protocols 2010(6):pdb.prot5448.

Nagel CW and Wulf LW. 1979. Changes in the Anthocyanins, Flavonoids and Hydroxycinnamic Acid Esters during Fermentation and Aging of Merlot and Cabernet Sauvignon. American Journal of Enology and Viticulture 30(2):111-116.

Nielsen JC and Richelieu M. 1999. Control of flavor development in wine during and after malolactic fermentation by Oenococcus oeni. Applied and environmental microbiology 65(2):7405.

Ou S and Kwok KC. 2004. Ferulic acid: pharmaceutical functions, preparation and applications in foods. Journal of the Science of Food and Agriculture 84(11):1261-1269.

Peng Y et al. 2012. IDBA-UD: a de novo assembler for single-cell and metagenomic sequencing data with highly uneven depth. Bioinformatics (Oxford, England) 28(11):1420-8.

Petersen TN et al. 2017. MGmapper: Reference based mapping and taxonomy annotation of metagenomics sequence reads. PLOS ONE 12(5):p.e0176469.

Pina $\mathrm{C}$ et al. 2004. Ethanol tolerance of five non-Saccharomyces wine yeasts in comparison with a strain of Saccharomyces cerevisiae influence of different culture conditions. Food Microbiology 21(4):439-447.

Rosi I, Vinella M and Domizio P. 1994. Characterization of beta-glucosidase activity in yeasts of oenological origin. The Journal of applied bacteriology 77(5):519-27. 
bioRxiv preprint first posted online Nov. 8, 2017; doi: http://dx.doi.org/10.1101/216390. The copyright holder for this preprint

(which was not peer-reviewed) is the author/funder, who has granted bioRxiv a license to display the preprint in perpetuity.

All rights reserved. No reuse allowed without permission.

806 Rumbold K et al. 2003. Purification and properties of a feruloyl esterase involved in lignocellulose

807 degradation by Aureobasidium pullulans. Applied and environmental microbiology 69(9):5622-6.

808 Sieuwerts S et al. 2008. Unraveling microbial interactions in food fermentations: from classical to

809 genomics approaches. Applied and environmental microbiology 74(16):4997-5007.

810 Sipiczki M. 2006. Metschnikowia strains isolated from botrytized grapes antagonize fungal and

811 bacterial growth by iron depletion. Applied and environmental microbiology 72(10):6716-24.

812 Suarez R et al. 2007. The production of ethylphenols in wine by yeasts of the genera Brettanomyces

813 and Dekkera: A review. Food Chemistry 102(1):10-21.

814

815

816

817

818

819

820

821

822

823

824

825

826

827

828

829

830 
bioRxiv preprint first posted online Nov. 8, 2017; doi: http://dx.doi.org/10.1101/216390. The copyright holder for this preprint (which was not peer-reviewed) is the author/funder, who has granted bioRxiv a license to display the preprint in perpetuity. All rights reserved. No reuse allowed without permission.

\section{Tables}

833 Table 1. Statistics of the sequencing and the mapping to the genomes of the inoculants.

\begin{tabular}{|c|c|c|c|c|}
\hline Sample & $\begin{array}{c}\text { Cleaned } \\
\text { reads }\end{array}$ & $\begin{array}{c}\% \\
\text { Unmapped } \\
\text { reads }\end{array}$ & $\begin{array}{c}\text { O. oeni* } \\
\text { coverage }\end{array}$ & $\begin{array}{c}\text { B. } \\
\text { bruxellensis** } \\
\text { coverage }\end{array}$ \\
\hline Control_1 & $3,317,232$ & 21 & 2.75 & 0.35 \\
\hline Control_2 & $5,195,056$ & 15.23 & 4.45 & 0.88 \\
\hline Brett_A_3 & $4,107,740$ & 8.54 & 1.15 & 26.3 \\
\hline Brett_A_4 & $6,695,169$ & 8.41 & 18.1 & 38.7 \\
\hline Brett_B_5 & $2,761,092$ & 2.08 & 70.65 & 0.4 \\
\hline Brett_B_6 & $10,993,754$ & 2.04 & 420 & 0.45 \\
\hline Brett_C_7 & $13,827,278$ & 3.25 & 399.8 & 23.27 \\
\hline Brett_C_8 & $2,054,860$ & 4.35 & 14.35 & 12.97 \\
\hline OEP_A_9 & $8,067,295$ & 7.9 & 43.85 & 27.2 \\
\hline OEP_A_10 & $65,488,400$ & 5.54 & 769.5 & 66.26 \\
\hline OEP_B_11 & $59,758,655$ & 1.91 & 2369.1 & 7.9 \\
\hline OEP_B_12 & $19,900,342$ & 1.89 & 216.25 & 3.37 \\
\hline OEP_C_13 & $39,001,458$ & 3.59 & 945.75 & 105.4 \\
\hline OEN_A_15 & $43,950,984$ & 4.27 & 1333 & 21 \\
\hline OEN_A_16 & $6,728,890$ & 10.18 & 4.3 & 44.6 \\
\hline OEN_B_17 & $37,224,934$ & 2.12 & 1280.85 & 2.12 \\
\hline OEN_B_18 & $159,467,366$ & 2.08 & 4621.2 & 13 \\
\hline OEN_C_19 & $6,443,410$ & 6.41 & 1.25 & 37.4 \\
\hline OEN_C_20 & $6,458,253$ & 6.19 & 110.5 & 26.3 \\
\hline OEP_21 & $65,477,885$ & 1.17 & 5.8 & 1.29 \\
\hline OEP_22 & $6,451,292$ & 9.15 & 8.785 & 1.23 \\
\hline OEN_23 & $1,831,535$ & 51 & 0.635 & 0.13 \\
\hline OEN_24 & $7,664,243$ & 3.6 & 47.25 & 0.9 \\
\hline Rep0rtd & 5959 & \\
\hline
\end{tabular}

$834 *$ Reported mapping statistics for $O$. oeni derive from the average of the mapping versus the

835 genomes of OEP and OEN. **Reported mapping statistics for B. bruxellensis derive from mapping 836 versus the publicly available genome of Brett_C strain. 


\section{Figures}

845

A)

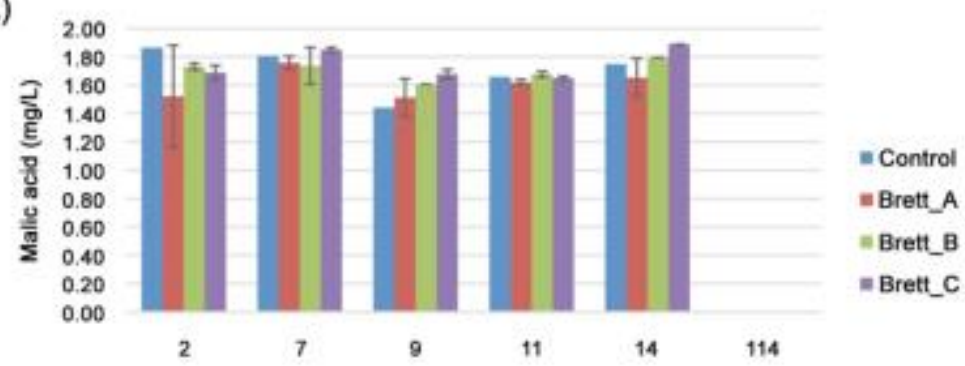

B)

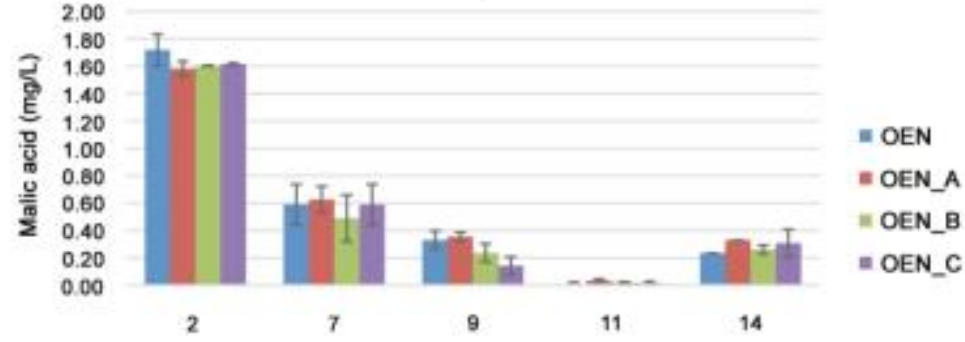

C)

Days

847 Figure 1. Concentration of malic acid (g/L) over time (days). Malic acid concentrations are

848 average values of duplicates. Error bars are standard deviations. A) Malic acid concentration on

849 inoculations with B. bruxellensis strain A, B or C. The concentrations on day 114 were $0 \mathrm{mg} / \mathrm{L}$

850 malic acid in all inoculations, suggesting any identified $O$. oeni in those samples are not able to

851 perform MFL, and are thus likely derived from the grape flora. B) Wines inoculated with OEN and

B. bruxellensis strain A, B or C. C) Wines inoculated with OEP and B. bruxellensis strain A, B or C. 
bioRxiv preprint first posted online Nov. 8, 2017; doi: http://dx.doi.org/10.1101/216390. The copyright holder for this preprint (which was not peer-reviewed) is the author/funder, who has granted bioRxiv a license to display the preprint in perpetuity. All rights reserved. No reuse allowed without permission.

A) 10
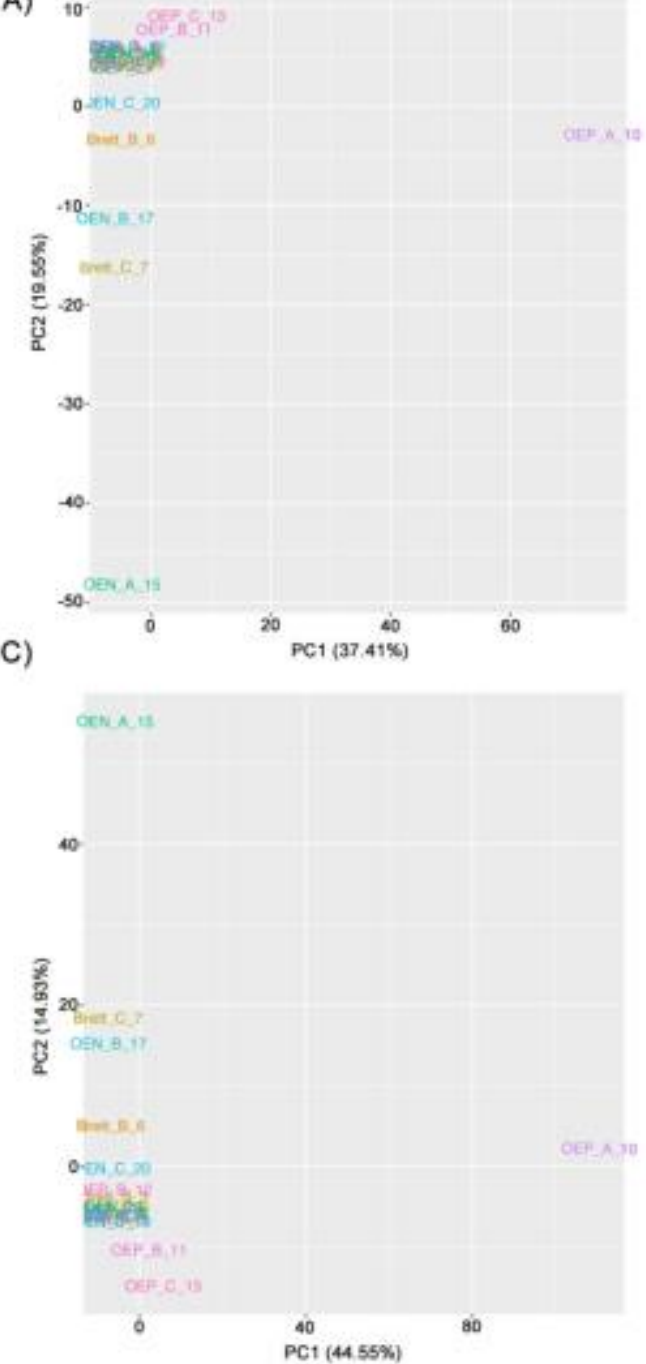

B)
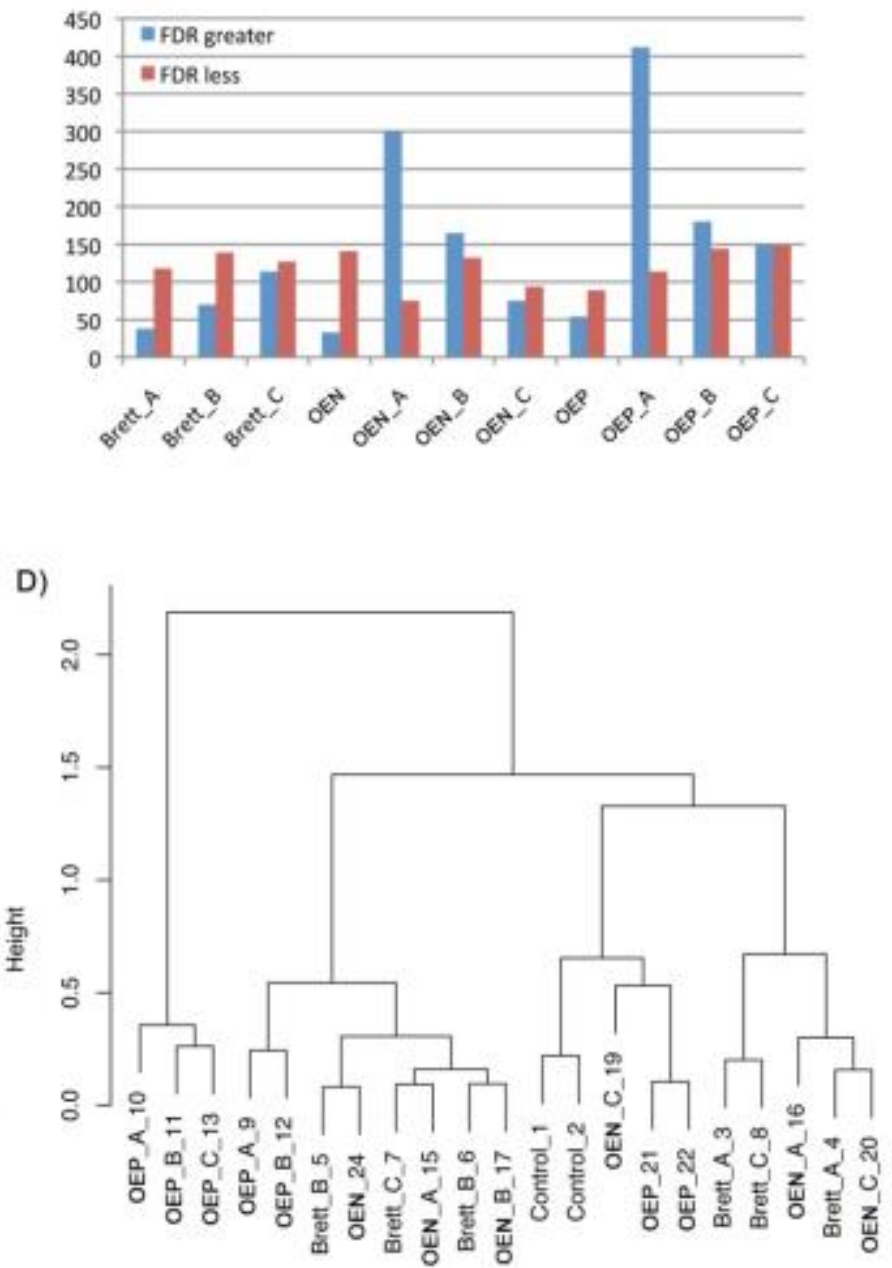

Figure 2. Bacterial profiling. A) PCA of the bacterial taxa at species level. B) Differentially abundant bacterial species by inoculation type compared to the control samples. FDR greater denotes the bacteria that was in statistically significant higher abundance, and FDR less are those in statistically significant less abundant. C) Cladogram of ward.D clustered Bray distances of all the microbial taxa from the samples. D) PCA of the abundance of all the identified microbial taxa. 
A) 9

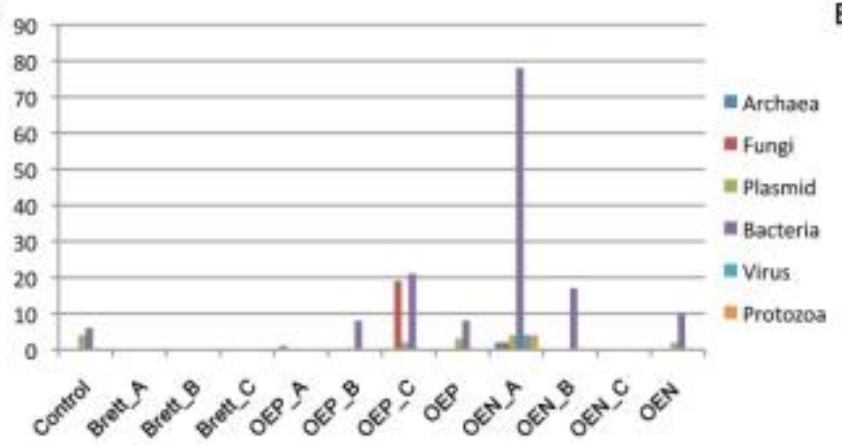

B)

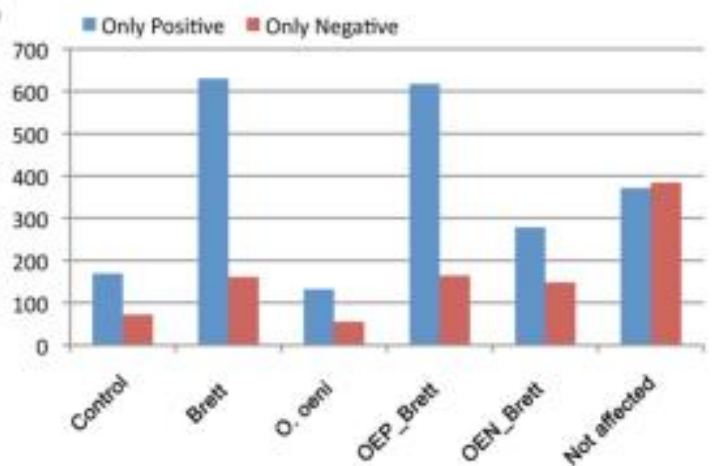

868

869

Figure 3. Taxonomic profiling. A) Microbial species taxonomic cores (i.e. the taxa present only in anyone of the replicates of each of the inoculation types). The general low number of identified cores highlights the low diversity in the wine microbial community, but the high number of taxa identified only in OEN_A show a high impact of the inoculation on the microbial diversity. B)

Microbial abundance correlations. Correlations identified only when removing from the comparisons the values from a given inoculation type are called to be disrupted to by that inoculation type. Correlations identified regardless of removing any of the inoculation types are called "not affected correlations". 
bioRxiv preprint first posted online Nov. 8, 2017; doi: http://dx.doi.org/10.1101/216390. The copyright holder for this preprint (which was not peer-reviewed) is the author/funder, who has granted bioRxiv a license to display the preprint in perpetuity. All rights reserved. No reuse allowed without permission.

A)

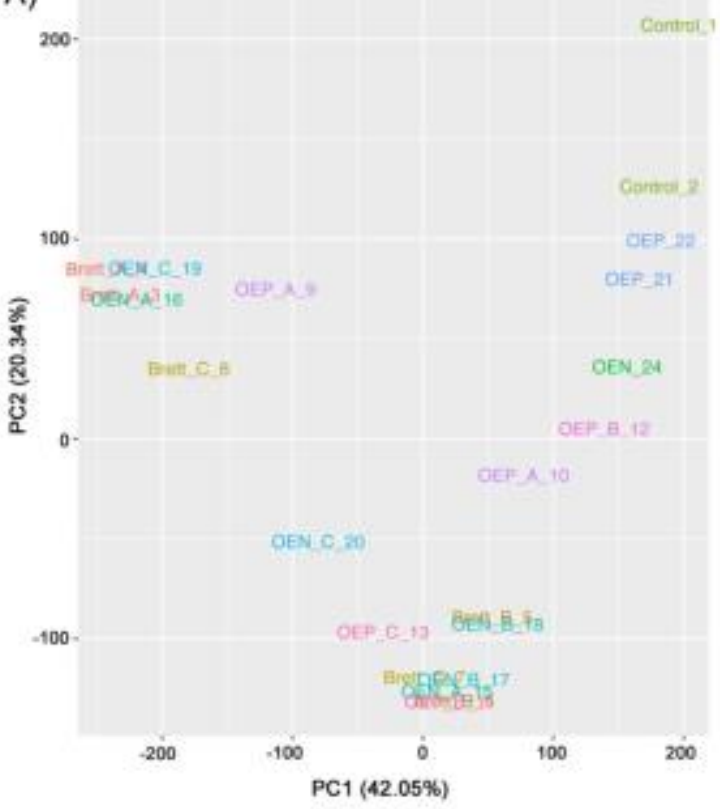

B)

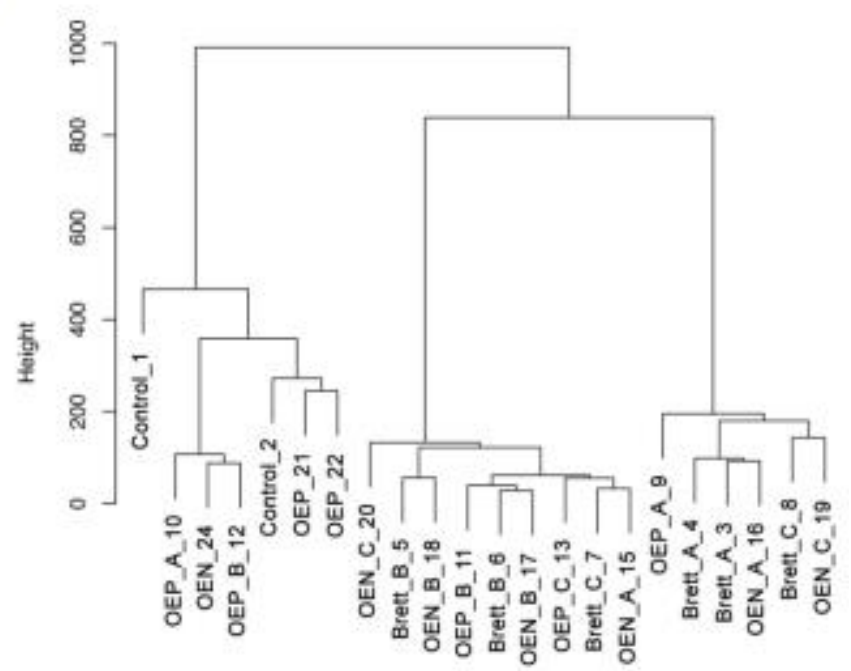

888 Figure 4. Functional profiling. A) PCA of the normalized gene mapping counts. B) Cladrogram of 889 the Euclidean distances clustered by the ward.D method. 
A)

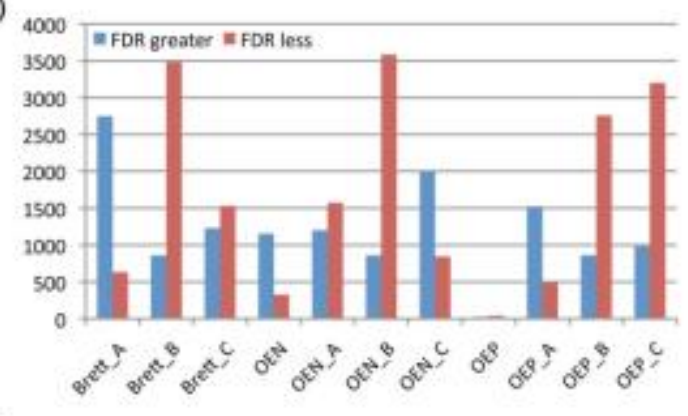

C)

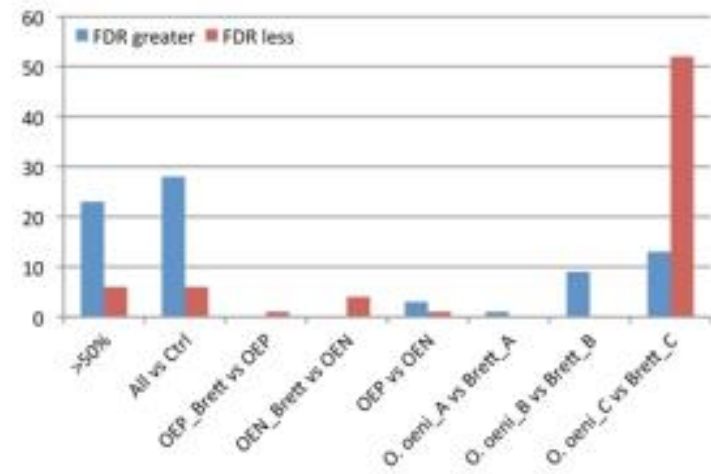

B)
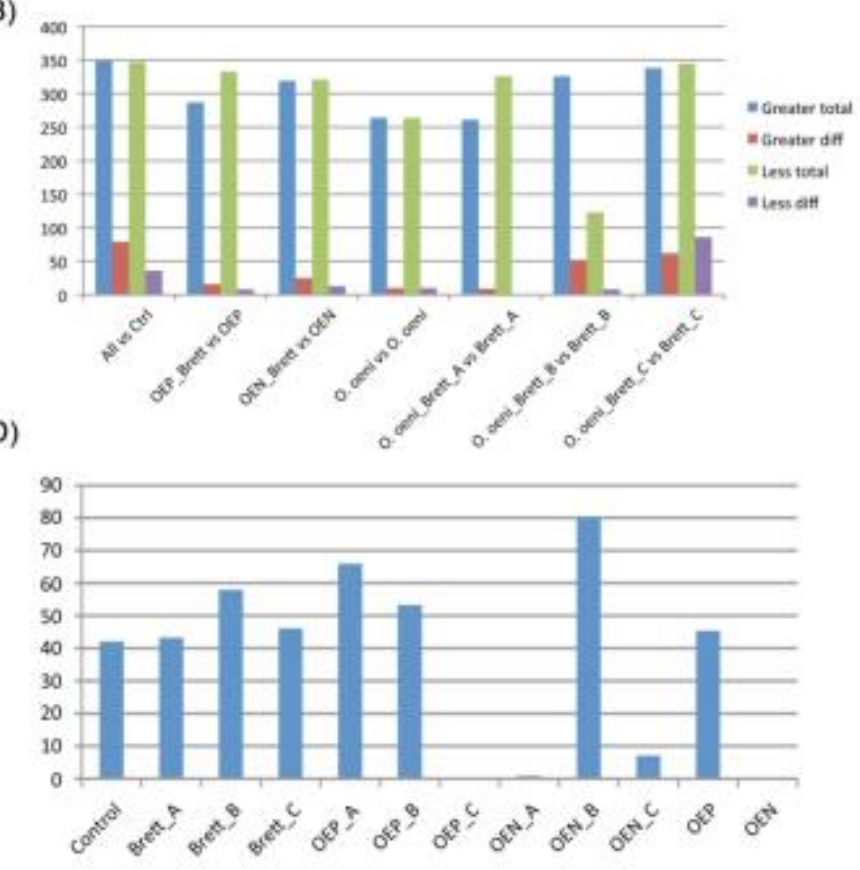

904 Figure 5. A) Differentially abundant KOs from the different inoculation types compared to the control. FDR greater denotes the KOs in statistically significant higher abundance, and FDR less are

906 those in statistically significant less abundant. B) Pathways from the differentially abundant KOs. have a replicate to consider. 